\title{
Solvothermal synthesis of a new 3-D mixed-metal sulfide framework, (H1.33tren)[In2.67Sb1.33S8]·tren
}

Article

Accepted Version

Creative Commons: Attribution-Noncommercial-No Derivative Works 4.0

Lampkin, J. D., Powell, A. V. and Chippindale, A. M. (2016) Solvothermal synthesis of a new 3-D mixed-metal sulfide framework, (H1.33tren)[In2.67Sb1.33S8].tren. Journal of Solid State Chemistry, 243. pp. 44-49. ISSN 0022-4596 doi: https://doi.org/10.1016/j.jssc.2016.08.007 Available at https://centaur.reading.ac.uk/66599/

It is advisable to refer to the publisher's version if you intend to cite from the work. See Guidance on citing.

Published version at: http://dx.doi.org/10.1016/j.jssc.2016.08.007

To link to this article DOI: http://dx.doi.org/10.1016/j.jssc.2016.08.007

Publisher: Elsevier

All outputs in CentAUR are protected by Intellectual Property Rights law, including copyright law. Copyright and IPR is retained by the creators or other copyright holders. Terms and conditions for use of this material are defined in the End User Agreement.

www.reading.ac.uk/centaur 
Central Archive at the University of Reading

Reading's research outputs online 
Solvothermal synthesis of a new 3-D mixed-metal sulfide framework, $\left(\mathrm{H}_{1.33}\right.$ tren) $\left[\mathrm{In}_{2.67} \mathrm{Sb}_{1.33} \mathrm{~S}_{8}\right] \cdot$ tren

John D. Lampkin, Anthony V. Powell and Ann M. Chippindale

Department of Chemistry, University of Reading, Whiteknights, Reading, RG6 6AD

Corresponding Author: Ann M Chippindale

j.lampkin@pgr.rdg.ac.uk

a.v.powell@rdg.ac.uk

a.m.chippindale@ rdg.ac.uk 


\section{Abstract}

A new indium(III) antimony(V) sulfide, ( $\left.\mathrm{H}_{1.33} \operatorname{tren}\right)\left[\operatorname{In}_{2.67} \mathrm{Sb}_{1.33} \mathrm{~S}_{8}\right] \cdot \operatorname{tren}$, has been prepared solvothermally at $433 \mathrm{~K}$. The compound crystallises in the tetragonal space group I-42d (lattice parameters, $a=12.6248(5)$ and $c=19.4387(18) \AA$ at $150 \mathrm{~K}$ ) and contains adamantane-like T2 supertetrahedral units comprised of corner-sharing $\mathrm{InS}_{4}{ }^{5-}$ and $\mathrm{SbS}_{4}{ }^{3-}$ tetrahedra. The adamantane-like units are then linked through sulfur vertices to generate an open, 3-D framework structure containing large pores in which neutral, protonated tren (tris(2-aminoethylene)amine) molecules reside. The presence of the organic components was confirmed by solid-state ${ }^{13} \mathrm{C}$ NMR $(10 \mathrm{kHz})$, combustion and thermogravimetric analysis. The band gap, obtained from UV-vis diffuse reflectance measurements, is $2.7(2) \mathrm{eV}$. Stirring with either water or alkalimetal salt solution leads to removal of the neutral tren molecules and an $~ 9 \%$ reduction in unit-cell volume on formation of $\left(\mathrm{H}_{1.33} \operatorname{tren}\right)\left[\mathrm{In}_{2.67} \mathrm{Sb}_{1.33} \mathrm{~S}_{8}\right] \cdot\left(\mathrm{H}_{2} \mathrm{O}\right)_{4}$.

\section{Keywords:}

Solvothermal synthesis; Crystal structure; Band gap; Antimony Indium Sulfide; Mixed-metal T2 supertetrahedra

\section{Introduction}

Open-framework materials have a variety of technological applications in, for example, catalysis [1], nuclear reprocessing [2], optical and chemical sensing [3] and ion exchange [4]. Aluminosilicate zeolites, with their large surface areas and welldefined pore sizes, have long been exploited, particularly in the fields of catalysis, molecular sieving and ion exchange. Open-framework chalcogenides offer advantages 
over the electrically insulating zeolites for some applications, as they combine porosity with semiconducting behaviour. Recent research has sought to create semiconducting chalcogenide-based materials in which the band gap is tuned to enable them to be used as chemical sensors [5] and photocatalysts [6].

The number of open-framework structures derived from the chalcogenides has increased steadily since the discovery of the group 15 sulfide, $\mathrm{K}_{2} \mathrm{Sb}_{4} \mathrm{~S}_{7}$, by Shafer et al. [7]. Subsequently, Bedard and co-workers demonstrated that chalcogenides can be synthesised under solvothermal conditions, at moderate temperatures and pressures, in the presence of amines as structure directing agents [8]. This solvothermal approach [9], including hydrothermal and more recently ionothermal methods, has led to the synthesis of many chalcogenides with 3-D framework structures [10], [11] as well as lower dimensional structures containing layers $[12,13,14]$ or chains $[15,16]$.

The products obtained from solvothermal reactions are influenced by a variety of reaction variables including temperature, pressure, time, heating/cooling rates and $\mathrm{pH}$, as well as the nature of the metal and chalcogen sources and the structure-directing amine. Reaction reproducibility can be an issue, particularly given the metastable nature of many of the product phases. Whilst the detailed mechanism of solvothermal synthesis remains poorly understood, it has been recognized [15], [17] that the synthesis of open-framework main group chalcogenide structures proceeds via the formation of simple building units, including primary species such as $\mathrm{MS}_{4}$ tetrahedra and $\mathrm{MS}_{3}$ trigonal pyramids [18] and larger secondary units, such as semi cubes, $\mathrm{Sb}_{3} \mathrm{~S}_{6}{ }^{3-}$ [19], and supertetrahedra [20]. Linkage of such units in the presence of an organic amine as structure-directing agent can lead to the formation of an extended framework, the negative charge of which is balanced by protonation of the amine. Additional structural variability, and tailoring of electronic properties, may be 
achieved by the introduction of transition-metal cations in the reaction mixture [21]. Whilst transition metals frequently form cationic complexes with amines that can in turn serve to balance the negative charge of the chalcogenide framework [22], [23], they may also be incorporated directly into the framework, with or without coordinated amine, as observed in $\left[\mathrm{Co}(\operatorname{tren}) \operatorname{InSbS}_{4}\right][24],\left[\mathrm{Mn}_{4}\left(2,2^{\prime}-\right.\right.$ bipyridine $\left.)_{2} \mathrm{Sb}_{4} \mathrm{~S}_{10}\right]$ [25], [ $\mathrm{Mn}_{2}($ phen $\left.)\left(\mathrm{Sb}_{2} \mathrm{~S}_{5}\right)\right]$ [26] and $\left[\mathrm{Mn}_{2}(\operatorname{api})\left(\mathrm{Sb}_{2} \mathrm{~S}_{5}\right)\right]($ api $=\mathrm{N}-(3-$ aminopropyl)-imidazole) [27]. Incorporation of transition-metal ions has also been seen in other framework chalcogenides, such as selenides [28] and tellurides [29].

An alternative strategy for the creation of novel phases is to exploit the complementary coordination preferences of different main-group elements. In this work, we focus on mixed indium-antimony sulfides. Indium(III) chalcogenides are constructed from tetrahedral $\mathrm{InS}_{4}$ building blocks which can link together to form discrete supertetrahedra $\operatorname{Tn}(n=2$ [25, 30] 3 [31], 4 [32], 5 [32]), existing either as anions, e.g. in the case of the T2 units as $\left[\operatorname{In}_{4} \mathrm{~S}_{10}\right]^{8-}$ ions [25], or terminated by $\mathrm{S}-\mathrm{H}$ groups, as in $\left[\mathrm{C}_{6} \mathrm{H}_{16} \mathrm{~N}\right]\left[\mathrm{In}_{4} \mathrm{~S}_{6}(\mathrm{SH})_{4}\right]$ [30]. The larger indium-sulfide based $\mathrm{T} 4$ and $\mathrm{T} 5$ supertetrahedra are usually stabilised on incorporation of a divalent metal cation, as is found in $\left[\mathrm{Cd}_{4} \operatorname{In}_{16} \mathrm{~S}_{31}\right]^{6-}$ and $\left[\mathrm{Cd}_{13} \operatorname{In}_{22} \mathrm{~S}_{52}\right]^{12-}[32]$. As well as existing as discrete units, the supertetrahedra can be connected via corner sharing to generate frameworks, as found in $\mathrm{KInS}_{2}$ [33], which contains $\mathrm{T} 2$ units linked to form a layered structure and $\left[\operatorname{In}_{10} \mathrm{~S}_{18}\right]^{6-}[34]$ and $\left[M_{4} \operatorname{In}_{16} \mathrm{~S}_{33}\right]^{10-}(M=\mathrm{Mn}, \mathrm{Co}, \mathrm{Zn}, \mathrm{Cd})$ [35], which consist of 3-D frameworks constructed from T3 and T4 supertetrahedra, respectively. Alternatively, indium-sulfide supertetrahedra may be joined through a variety of inorganic linkers, such as $\mathrm{InS}_{4}{ }^{5-}$ tetrahedra, as in $\mathrm{T} 3$ containing $(\mathrm{DEA}-\mathrm{H})_{7} \mathrm{In}_{11} \mathrm{~S}_{21} \mathrm{H}_{2} \quad(\mathrm{DEA}=$ diethylammonium) [ 36 ] or $\mathrm{SbS}_{3}{ }^{3-}$ trigonal pyramids, as in $\mathrm{T} 2$ containing $\left[\mathrm{NH}_{3} \mathrm{CH}_{3}\right]_{4}\left[\mathrm{In}_{4} \mathrm{SbS}_{9}(\mathrm{SH})\right][4]$. 
By contrast, antimony shows greater geometrical variety of primary building units [37]. In the $\mathrm{Sb}(\mathrm{III})$ oxidation state, $\mathrm{SbS}_{3}$ trigonal-pyramidal geometry is favoured, although an $\mathrm{SbS}_{4}$ see-saw geometry is also known, whilst $\mathrm{Sb}(\mathrm{V})$ adopts a tetrahedral $\mathrm{SbS}_{4}$ arrangement. Only a few mixed $\mathrm{Sb}(\mathrm{III})-\mathrm{In}(\mathrm{III})$ sulfides have been reported to date [37], including $\left[\mathrm{Co}(\text { dien })_{2}\right]_{2} \mathrm{In}_{2} \mathrm{Sb}_{4} \mathrm{~S}_{11}$ (dien $=$ diethylenetriamine) [38], which consists of chains constructed from $\mathrm{InS}_{4}$ tetrahedra, $\mathrm{SbS}_{3}$ trigonal pyramids and $\mathrm{SbS}_{4}$ see-saw units, $\left[\left(\mathrm{CH}_{3} \mathrm{CH}_{2} \mathrm{CH}_{2}\right)_{2} \mathrm{NH}_{2}\right]_{5} \mathrm{In}_{5} \mathrm{Sb}_{6} \mathrm{~S}_{19} \cdot 1.45 \mathrm{H}_{2} \mathrm{O}$ and $\left[\left(\mathrm{CH}_{3}\right)_{2} \mathrm{NH}_{2}\right]_{2} \mathrm{In}_{2} \mathrm{Sb}_{2} \mathrm{~S}_{7}$, both of which have 2-D structures [ 39] and [Co(dap) $\left.\left.)_{3}\right] \operatorname{InSb}_{3} \mathrm{~S}_{7}\right]$ (dap = 1,2diaminopropane) [40], a 3-D framework containing large channels constructed from $\mathrm{InS}_{4}$ and $\mathrm{SbS}_{3}$ units. In an additional compound, $\left[\mathrm{NH}_{3} \mathrm{CH}_{3}\right]_{4}\left[\mathrm{In}_{4} \mathrm{SbS}_{9}(\mathrm{SH})\right]$, indiumcontaining $\operatorname{In}_{4} \mathrm{~S}_{10} \mathrm{~T} 2$ adamantane units are linked through their terminal sulfur atoms by $\mathrm{SbS}_{3}$ trigonal pyramids to create a 3-D framework [4].

To the best of our knowledge, there are no examples of frameworks containing mixed Sb-In T2 supertetrahedra. Here, we describe the synthesis and characterisation of the first mixed-metal indium(III)-antimony(V) sulfide, $\left(\mathrm{H}_{1.33}\right.$ tren)[ $\left.\operatorname{In}_{2.67} \mathrm{Sb}_{1.33} \mathrm{~S}_{8}\right]$-tren. This contains a three-dimensional framework constructed entirely from vertex-linked T2 supertetrahedra, in which $\mathrm{Sb}(\mathrm{V})$ and $\mathrm{In}(\mathrm{III})$ are disordered over the tetrahedral sites. We demonstrate, using a range of techniques, that the pore space contains both neutral and protonated amines. On stirring the compound in either water or an alkali-metal halide solution, the neutral tren molecules can be removed from the pores and replaced by water molecules with retention of the indium-antimony sulfide framework and charge balancing protonated amine. 


\section{Experimental}

\subsection{Synthesis}

The title compound, $\left(\mathrm{H}_{1.33}\right.$ tren $)\left[\mathrm{In}_{2.67} \mathrm{Sb}_{1.33} \mathrm{~S}_{8}\right] \cdot$ tren, was synthesised from a mixture of $\mathrm{Sb}_{2} \mathrm{~S}_{3}(67 \mathrm{mg} 0.20 \mathrm{mmol}), \mathrm{InCl}_{3}(160 \mathrm{mg}, 0.72 \mathrm{mmol}), \mathrm{CoS}$ (34 mg, $\left.0.37 \mathrm{mmol}\right), \mathrm{S}$ (42 $\mathrm{mg}, 1.31 \mathrm{mmol})$ and tris(2-aminoethyl)amine (tren) $(3.2 \mathrm{ml}, 21 \mathrm{mmol})$. The reagent mixture, initially of $p \mathrm{H} \sim 7$, was stirred for 10 minutes in a $23 \mathrm{ml}$ Teflon-lined stainless-steel autoclave before being heated at $160{ }^{\circ} \mathrm{C}$ for 5 days at a heating rate of 1 ${ }^{\circ} \mathrm{C} \min ^{-1}$. The products were then cooled overnight at $1{ }^{\circ} \mathrm{C} \min ^{-1}$ before being filtered and washed successively with ethanol, water and acetone. Single crystals in the form of yellow blocks were handpicked and corresponded to a yield of $c a .20 \%$ by weight of solid product. Combustion analysis gave values of C: $13.98 \%, \mathrm{H}: 3.98 \%$, N: 10.37 $\%$, respectively. These are in good agreement with the values calculated for the formula, ( $\left.\mathrm{H}_{1.33} \operatorname{tren}\right)\left[\operatorname{In}_{2.67} \mathrm{Sb}_{1.33} \mathrm{~S}_{8}\right] \cdot \operatorname{tren},(\mathrm{C}: 14.14 \%, \quad \mathrm{H}: 3.69 \%, \quad \mathrm{~N}: 10.99 \%)$ established from a combination of EDX, single-crystal X-ray diffraction, TGA and solid-state ${ }^{13} \mathrm{C}$ NMR results (vide infra). Powder X-ray diffraction data for the assynthesized product demonstrated that in addition to the title compound, $\mathrm{Sb}$ and $\mathrm{InSb}$ were present as minor impurity phases, together with an as yet unidentified phase. Although cobalt ions were included in the reaction mixture, no cobalt was detected in the title compound. Repeating the synthesis in the absence of cobalt led to a considerably lower yield of the title compound ( 3\%) suggesting that the transitionmetal ion aids crystallisation of the new indium-antimony sulfide. Such use of transition metals as mineralisers has previously been reported in the solvothermal synthesis of antimony sulfides [41]. 


\subsection{Characterisation}

The In:Sb ratio in the inorganic framework was determined from energy dispersive X-ray (EDX) data collected using a Cambridge 360 Stereoscan electron microscope fitted with an Oxford Instruments INCA EDX analysis system, and operating at $20 \mathrm{kV}$ and $200 \mathrm{pA}$. Single crystals of the title compound were dusted onto an adhesive carbon stub for analysis (See ESI, Table S1).

Powder X-ray diffraction patterns of the as-synthesised material and handpicked crystals were collected at room temperature over the range $\left(5<2 \theta /{ }^{\circ}<50\right)$ using a Bruker D8 Discover diffractometer $\left(\mathrm{Cu} \mathrm{K}_{\alpha}\right.$ radiation $\left(\lambda=\begin{array}{l}\lambda=5418 \AA \\ \AA\end{array}\right)$.

Thermogravimetric analysis was carried out using a TA instruments Q50 Thermogravimetric Analyser. Approximately $10 \mathrm{mg}$ of handpicked ground crystals were heated from room temperature to $400{ }^{\circ} \mathrm{C}$ at a rate of $5{ }^{\circ} \mathrm{C} \mathrm{min}-1$ under a flow of nitrogen.

IR spectra were collected over the range 550 to $4000 \mathrm{~cm}^{-1}$ using a Perkin Elmer Spectrum 100 FT-IR Spectrometer. A solid-state ${ }^{13} \mathrm{C}$ NMR spectrum was measured at $296 \mathrm{~K}$ using $100 \mathrm{mg}$ of finely ground hand-picked crystals on a Bruker Advance III $500 \mathrm{MHz}$, running ICON NMR 4.2 under TOPSPIN 2.4 using a $4 \mathrm{~mm}$ MAS ${ }^{15} \mathrm{~N} / 3$ probe. Diffuse reflectance data were collected over the range $9090-50,000 \mathrm{~cm}^{-1}$ using a Perkin Elmer UV-vis Spectrometer Lambda 35 spectrometer. $\mathrm{BaSO}_{4}$ was used as a reference for $100 \%$ reflectance. Measurements were made on $\sim 10 \mathrm{mg}$ of ground handpicked crystals. The Kubelka-Munk function was applied to the data to obtain the band gap [42]. 


\subsection{Crystal-structure determination}

Single-crystal X-ray diffraction data were collected at $150 \mathrm{~K}$ using graphitemonochromated MoK $\alpha$ radiation $(\lambda=0.71073 \AA)$ on an Oxford Diffraction Gemini $S$ Ultra X-ray diffractometer fitted with an Oxford Cryosystems Cryostream cooling device. Crystallographic details are summarized in Table 1 and in the ESI (Table S2).

The structure was solved using the program SIR92 [43] and the model refined using the CRYSTALS suite of programs [44]. From the structure solution, the inorganic framework had a In:Sb:S ratio of (4-x): $x$ : 8. The In and Sb occupancies, which could not be refined, were subsequently fixed in accordance with the EDX results (vide infra) to give the composition $\left[\operatorname{In}_{2.67} \mathrm{Sb}_{1.33} \mathrm{~S}_{8}\right]^{1.33-}$. The organic counterions are highly disordered and could not be located in difference Fourier maps. Therefore, the metal and sulfur framework atoms were refined anisotropically and Platon SQUEEZE [45] applied to model the electron density within the pores.

\section{Results and Discussion}

Analytical electron microscopy EDX measurements (Table S1) confirmed the presence of sulfur, indium and antimony in crystals of the title compound. The measured sulfur content was however lower than that expected for the crystallographically-determined framework composition, $\left[M_{4} \mathrm{~S}_{8}\right](M=(\mathrm{In}+\mathrm{Sb}))$. EDX measurements on a ground $\mathrm{Sb}_{2} \mathrm{~S}_{3}$ reference sample also gave a low sulfur content suggesting that sulfur volatilization had occurred under the high vacuum conditions of the electron microscope, as has previously been observed [46]. Therefore only the $\mathrm{In}: \mathrm{Sb}$ ratio could be determined reliably giving a ratio of In:Sb:S of 2.67(5): 1.33(5) : 8 in the inorganic framework. 
Table 1: Crystallographic data for $\left(\mathrm{H}_{1.33} \operatorname{tren}\right)\left[\operatorname{In}_{2.67} \mathrm{Sb}_{1.33} \mathrm{~S}_{8}\right] \cdot$ tren

Formula weight

Crystal Habit

Crystal system

Space group

Temp /K

$a / \AA$

$c / \AA$

$\mathrm{V} / \AA^{3}$

Z

Wavelength /

$\mu\left(\mathrm{mm}^{-1}\right)$

Total reflections $(I>3 \sigma(I))$

$R(F)$ factor

$w R(F)$ factor
1018.81

Yellow block

Tetragonal

$I-42 d$

150

$12.6248(5)$

19.4387(18)

3098.2(3)

4

0.71073

3.645

1044

0.0519

0.0542

The crystal structure contains only one metal site (16(e) site), hereafter denoted $M$, which was assigned the occupancy $(0.67 \mathrm{In}+0.33 \mathrm{Sb})$, in accordance with the EDX results. In the structure, the $M$ atom is coordinated by 4 sulfur atoms and has a slightly distorted tetrahedral geometry with bond lengths of 2.382(3) (M-S2), 2.412(4), and 2.451(4) $(M-\mathrm{S} 1)$ and $2.427(2) \AA(M-\mathrm{S} 3)$ with $\mathrm{S}-M-\mathrm{S}$ bond angles in the range 
$99.22(11)-117.03(4)^{\circ}$. The location of antimony in a tetrahedral environment provides compelling evidence for it being present as $\mathrm{Sb}(\mathrm{V})$. The $M-\mathrm{S}$ bond lengths are comparable with $\mathrm{Sb}(\mathrm{V})-\mathrm{S}$ distances of $2.399(7)-2.435(6) \AA$ found in discrete $\mathrm{SbS}_{4}{ }^{3-}$ tetrahedra [47] and $\mathrm{In}(\mathrm{III})-\mathrm{S}$ distances reported previously for an $\mathrm{In}_{4} \mathrm{~S}_{10}{ }^{8-} \mathrm{T} 2$ supertetrahedron [4] which lie in the range $2.444(2)-2.476(4) \AA$. The presence of $\mathrm{Sb}(\mathrm{V})$ and $\mathrm{In}(\mathrm{III})$ gives rise to a negatively charged framework with composition $\left[\operatorname{In}_{2.67} \mathrm{Sb}_{1.33} \mathrm{~S}_{8}\right]^{1.33-}$.

The $M S_{4}$ tetrahedra are linked through shared vertices to form adamantane-like T2 supertetrahedral clusters (Figure 1). The supertetrahedra are linked through terminal (S3) atoms, reminiscent of the linkage of $\mathrm{ZnS}_{4}$ tetrahedra in zinc blende, to form a 3-D metal-sulfur framework in which there are pores and channels (Figure 2). When van der Waals' radii are taken into consideration (Figure S1), the pore dimensions are ca. 5 $\times 4 \AA^{2}$ parallel to [100] (Figure 2(b)) and ca. $6 \times 6 \AA^{2}$ parallel to [111] (Figure 2(c)). The powder X-ray diffraction data for handpicked crystals show good agreement with the pattern calculated on the basis of the single-crystal diffraction study (Figures 3 and S2).

Although the tren molecules could not be located in the single-crystal X-ray study, evidence for their presence in the title compound is found in the infrared spectrum (Figure 4). Peaks at 3109 and $3182 \mathrm{~cm}^{-1}$ can be assigned to $v(\mathrm{~N}-\mathrm{H})$ vibrations, whilst an $\mathrm{H}-\mathrm{N}-\mathrm{H}$ bending vibration is observed at $1580 \mathrm{~cm}^{-1}$ and aliphatic amine $v(\mathrm{C}-\mathrm{N})$ vibration at $1078 \mathrm{~cm}^{-1}$. Further evidence for the presence of tren in the title compound is provided by the ${ }^{13} \mathrm{C}$ solid-state NMR spectrum (Figure 5). This reveals two peaks at 38.75 and $55.01 \mathrm{ppm}$ of relative intensity $1: 1$, consistent with equal numbers of carbon atoms in two different environments, as is found in the tren molecule. The difference 
in the width of the two peaks may be associated with the greater degree of freedom of the outer carbon atoms, leading to broadening of the peak at $55.01 \mathrm{ppm}$.

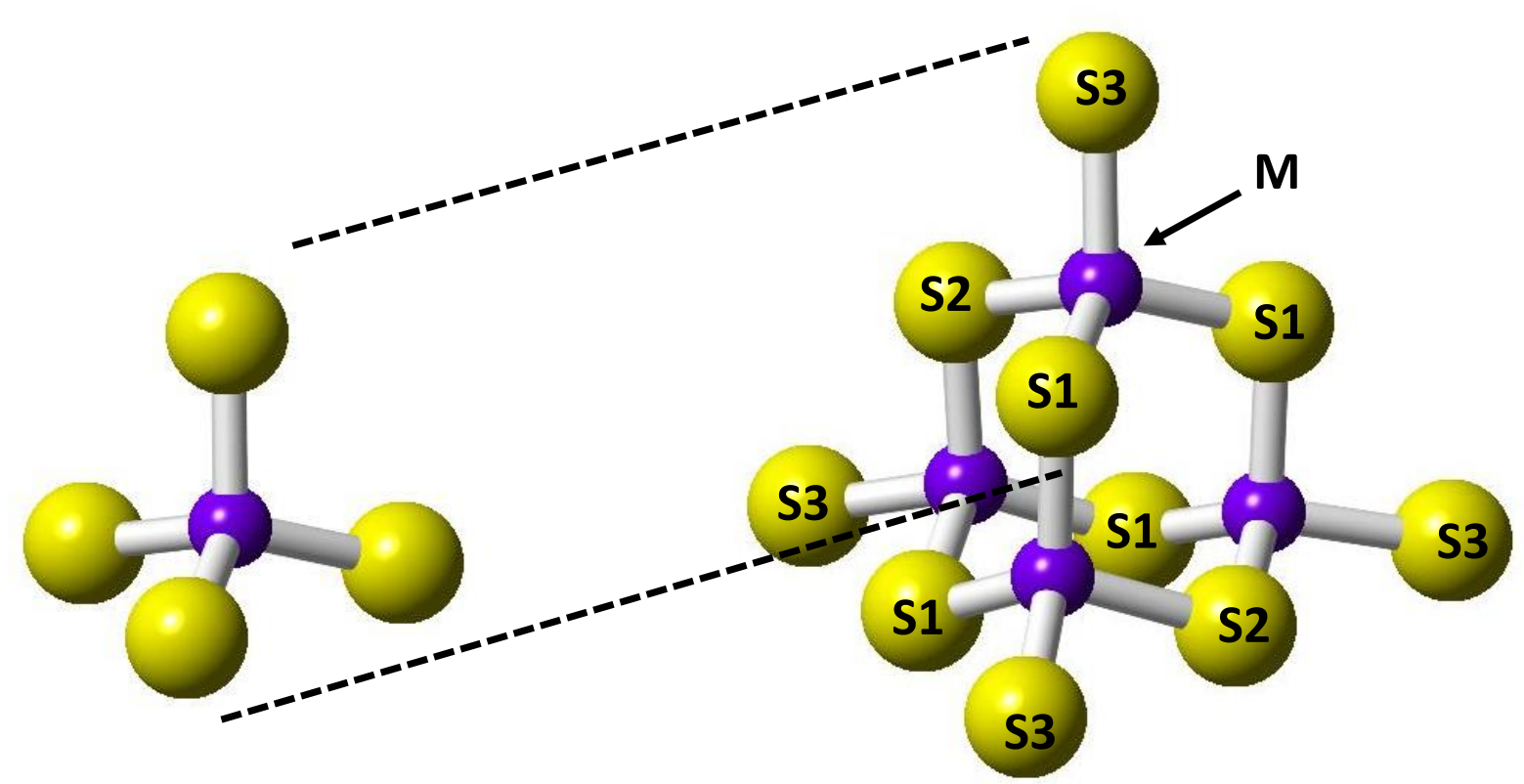

Figure 1: Linking of tetrahedral $M S_{4}$ primary building units to form $M_{4} S_{10}$ adamantane-like $\mathrm{T} 2$ clusters $(M=(0.67 \mathrm{In}+0.33 \mathrm{Sb}))$ in $\left(\mathrm{H}_{1.33} \operatorname{tren}\right)\left[\operatorname{In}_{2.67} \mathrm{Sb}_{1.33} \mathrm{~S}_{8}\right] \cdot$ tren. Key: Purple spheres: $M$, yellow spheres: $\mathrm{S}$. 
(a)

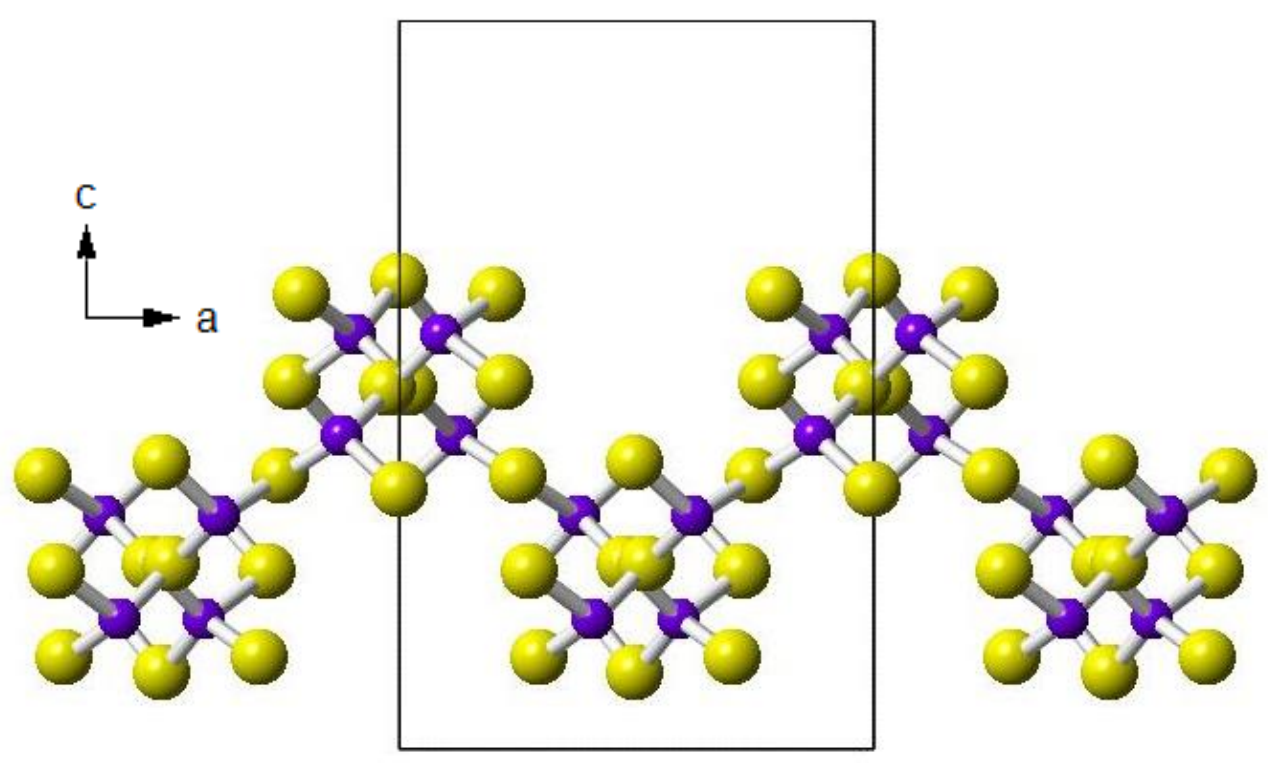

(b)

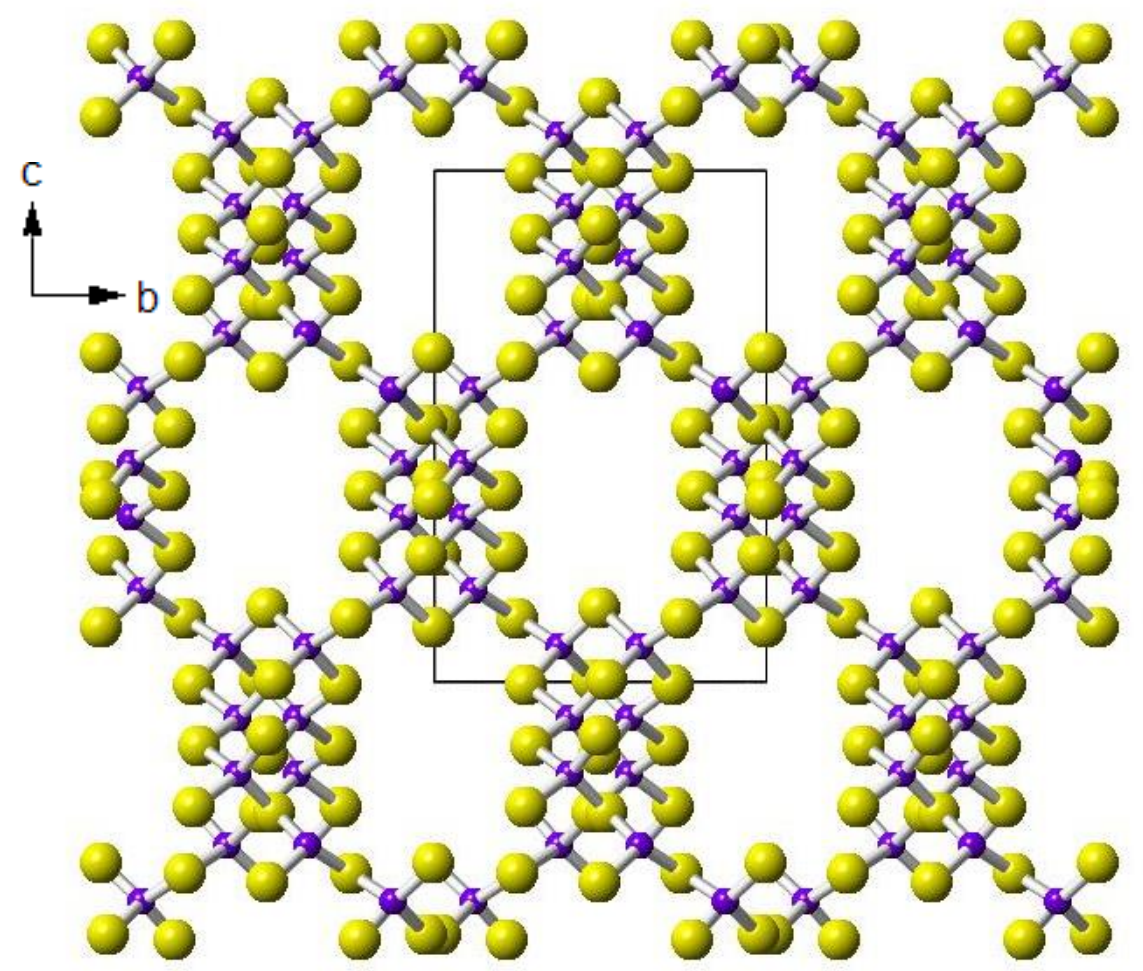


(c)

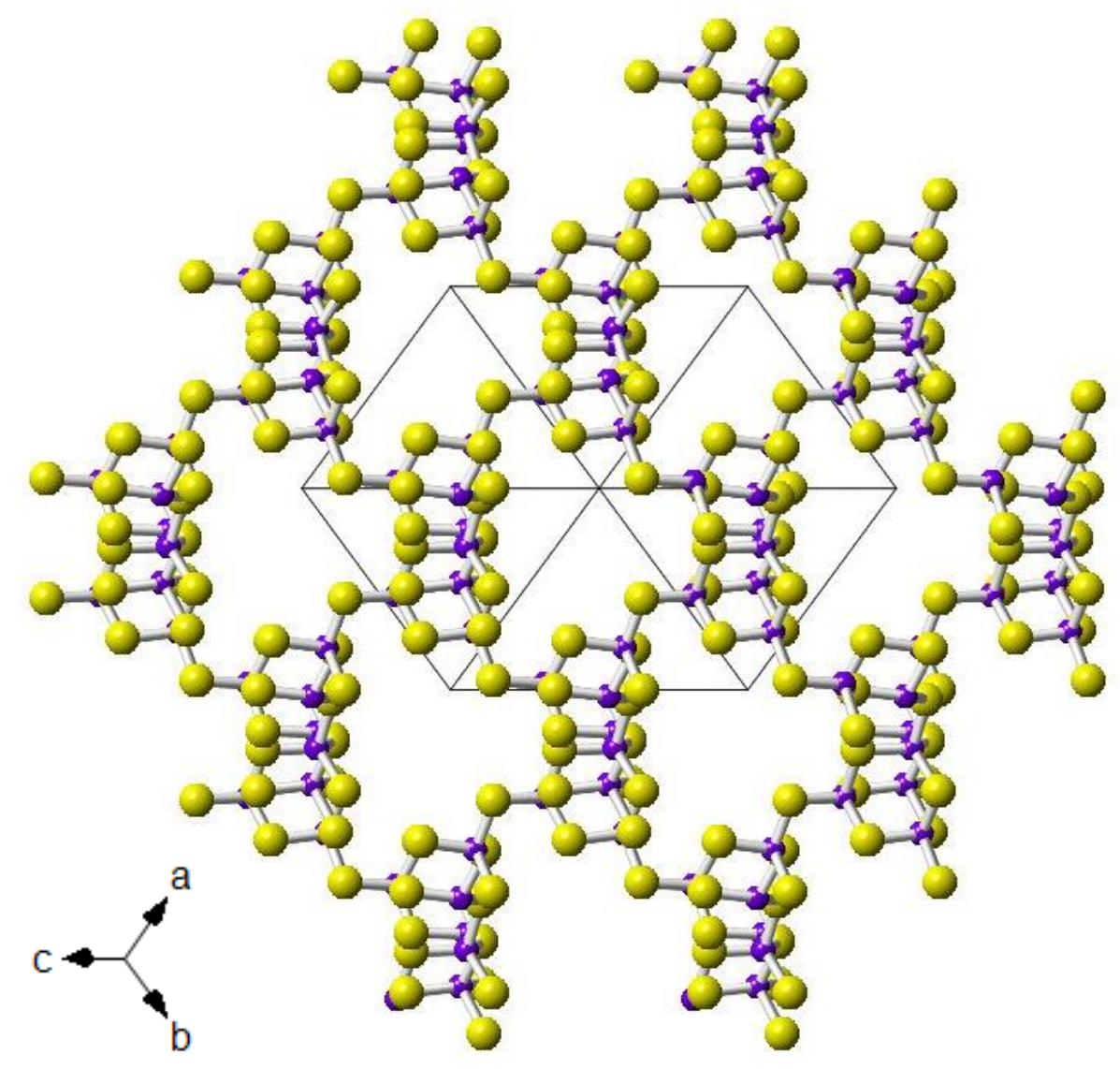

Figure 2: Views of the $\left[\operatorname{In}_{2.67} \mathrm{Sb}_{1.33} \mathrm{~S}_{8}\right]^{1.33-}$ framework in the title compound showing (a) the linking of T2 units to form zigzag chains directed along [010]; (b) the pores along the [100] direction and (c) the pores parallel to the [111] direction. Key: Purple spheres: $M$ atoms, yellow spheres: $\mathrm{S}$ atoms. 


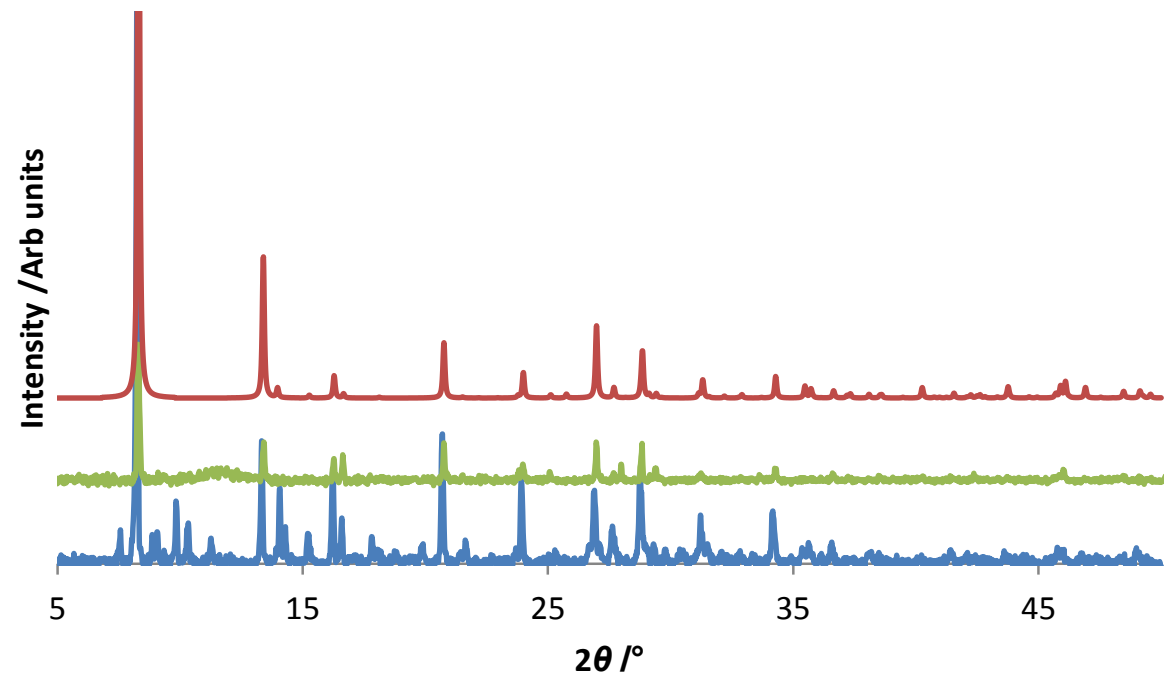

Figure 3: Powder X-ray diffraction patterns of the bulk as-synthesised product (blue), handpicked crystals (green) and the simulated pattern calculated from single-crystal diffraction data (red). Additional peaks in the as-synthesised product pattern correspond to $\mathrm{Sb}, \mathrm{InSb}$ and an as-yet unidentified phase (see ESI, Figure S2).

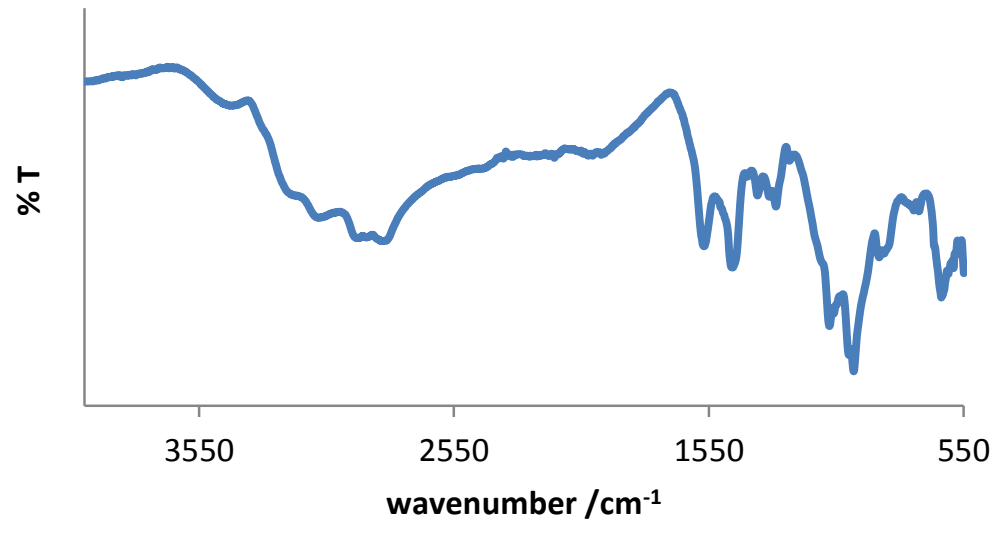

Figure 4: IR spectrum of $\left(\mathrm{H}_{1.33}\right.$ tren $)\left[\operatorname{In}_{2.67} \mathrm{Sb}_{1.33} \mathrm{~S}_{8}\right] \cdot$ tren 


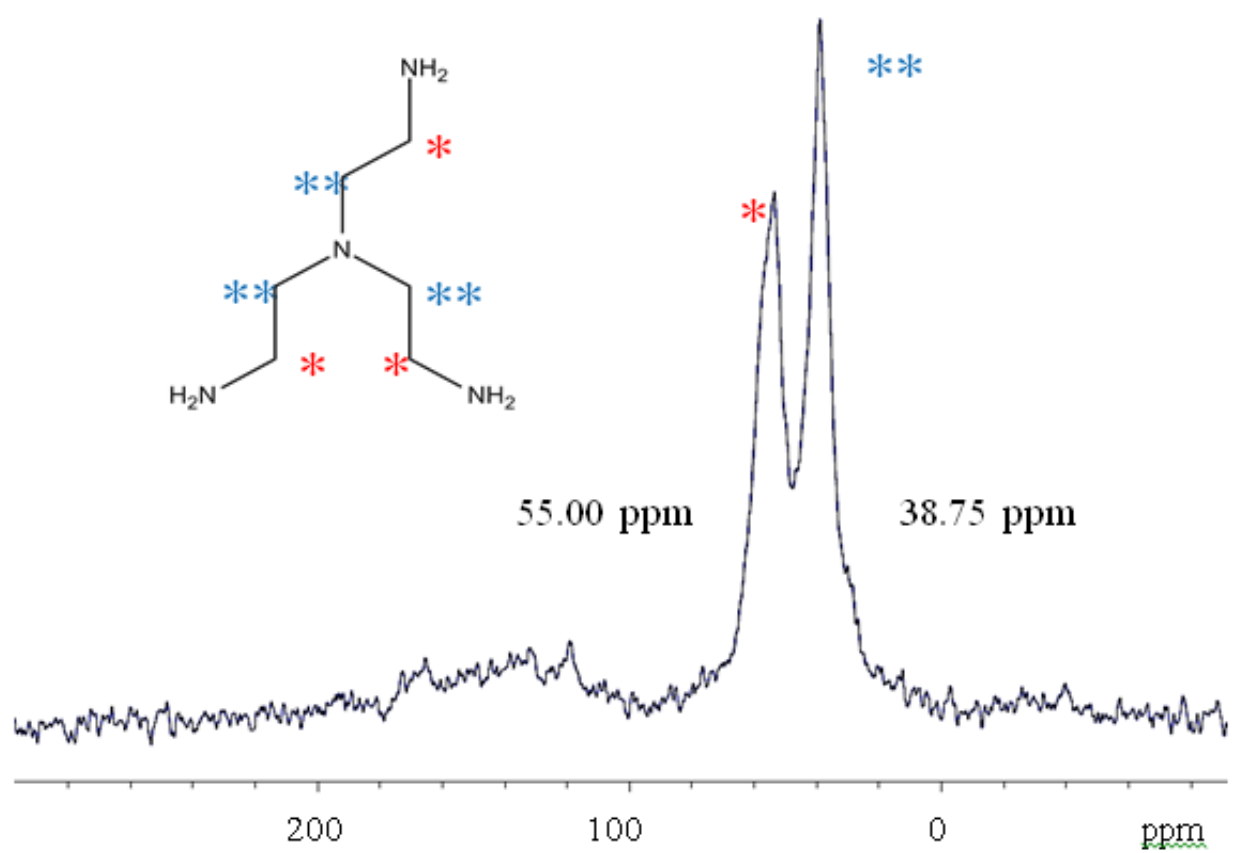

Figure 5: Solid-state ${ }^{13} \mathrm{C}$ NMR $(10 \mathrm{kHz})$ of $\left(\mathrm{H}_{1.33} \operatorname{tren}\right)\left[\operatorname{In}_{2.67} \mathrm{Sb}_{1.33} \mathrm{~S}_{8}\right]$-tren under $\mathrm{N}_{2}$. Key: Blue(**) inner carbon, red (*) outer carbon.

Thermogravimetric analysis of the title compound (Figure 6) reveals a total weight loss of $28.92 \%$ on heating the sample to $400{ }^{\circ} \mathrm{C}$. This is in good agreement with a value of $28.88 \%$ calculated for the loss of two tren molecules per formula unit, consistent with the formulation $\left(\mathrm{H}_{1.33} \operatorname{tren}\right)\left[\operatorname{In}_{2.67} \mathrm{Sb}_{1.33} \mathrm{~S}_{8}\right] \cdot$ tren, when the degree of protonation necessary to balance the framework charge is taken into account. The weight loss occurs in two stages of 9.62 and $19.28 \%$ at onset temperatures of 220 and $270{ }^{\circ} \mathrm{C}$, respectively (with corresponding maxima in the DTG curve at 252 and 274 $\left.{ }^{\circ} \mathrm{C}\right)$. The first weight loss corresponds to the loss of an ethylenediamine molecule that would arise on cyclisation of tren to piperazine. Thermal degradation of larger amines to generate ethylenediamine [48] and the rearrangement of polyamines under solvothermal conditions [49] have been reported previously. Combustion analysis of the product obtained on stopping the thermal analysis after the first weight loss gave: 
C: $12.26 \%, \mathrm{H}: 2.82 \%$ and $\mathrm{N}: 7.76 \%$, corresponding to $\mathrm{C}_{10} \mathrm{~N}_{5.4} \mathrm{H}_{28}$, which, within experimental error, is consistent with the presence of piperazine and tren in the pores. The second weight loss in the TGA further supports the loss of piperazine and tren on further heating to $260{ }^{\circ} \mathrm{C}$. The powder X-ray diffraction pattern of the final solid product from thermogravimetric analysis was poorly crystalline and could not be indexed (Figure S3).

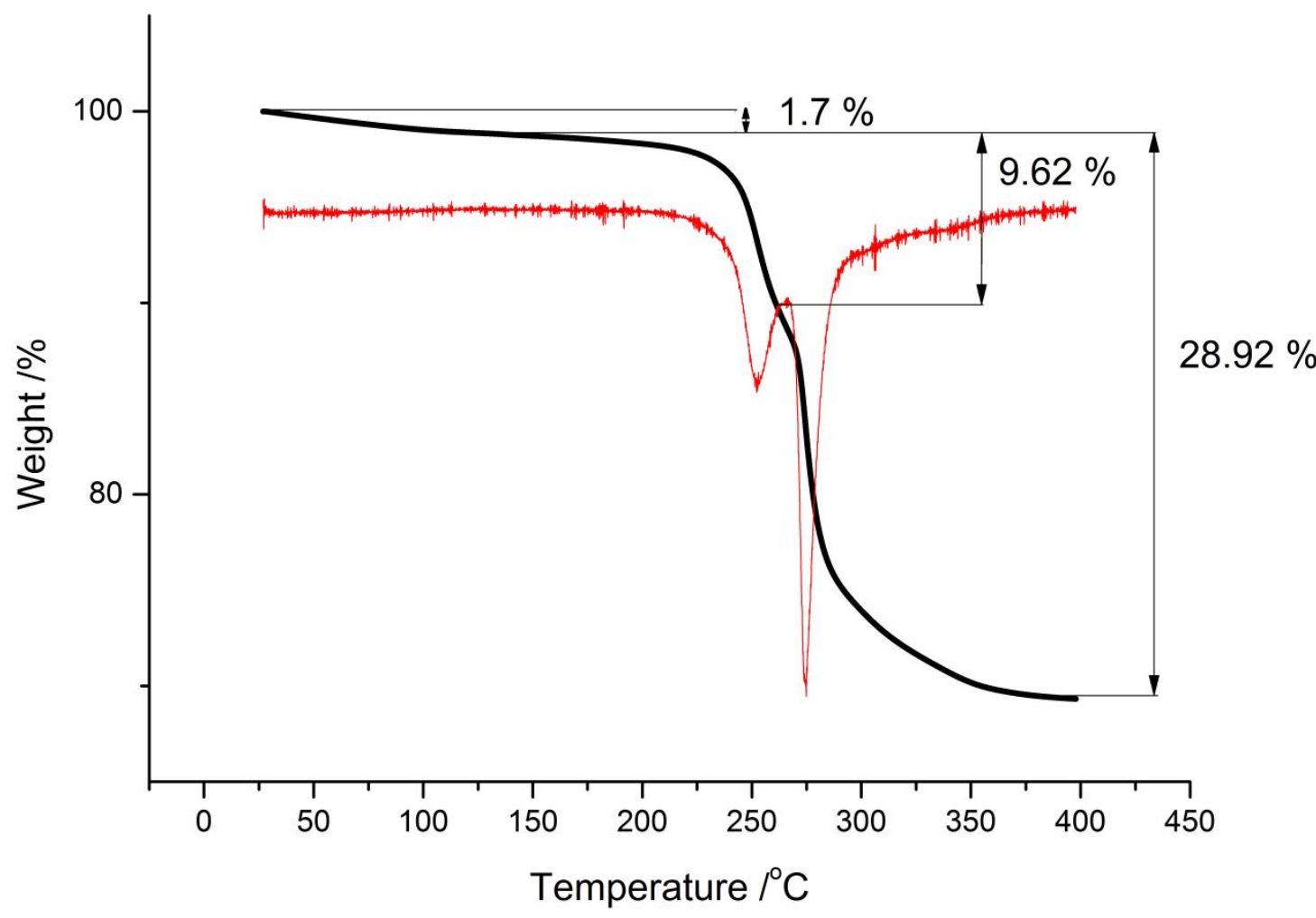

Figure 6: Thermogravimetric analysis curve of $\left(\mathrm{H}_{1.33} \operatorname{tren}\right)\left[\mathrm{In}_{2.67} \mathrm{Sb}_{1.33} \mathrm{~S}_{8}\right]$ 'tren heated under $\mathrm{N}_{2}$ (black) and the corresponding derivative (DTG) curve (red).

The diffuse reflectance spectrum (Figure 7) shows an optical band gap of 2.7(2) eV. When compared to the optical band gap versus metal centre density plot of Powell 
et al. formulated for thioantimonates [50] and bimetallic thiometallates [51], this compound falls on the trendline.

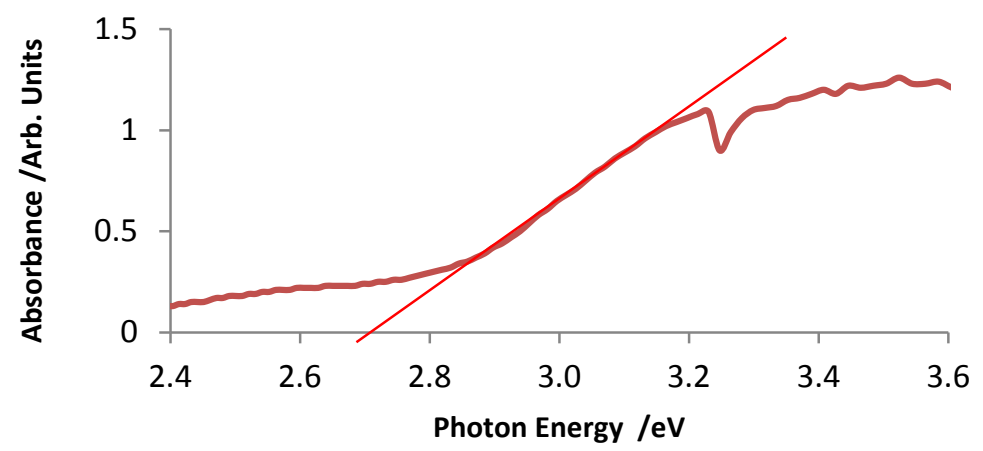

Figure 7: Diffuse reflectance spectrum of $\left(\mathrm{H}_{1.33} \operatorname{tren}\right)\left[\mathrm{In}_{2.67} \mathrm{Sb}_{1.33} \mathrm{~S}_{8}\right] \cdot$ tren

\subsection{Soaking $\left(H_{1.33}\right.$ tren $)\left[\operatorname{In}_{2.67} \mathrm{Sb}_{1.33} S_{8}\right] \cdot$ tren in water and metal-halide solutions}

In order to assess the potential ion-exchange capability of $\left(\mathrm{H}_{1.33}\right.$ tren)[ $\left.\operatorname{In}_{2.67} \mathrm{Sb}_{1.33} \mathrm{~S}_{8}\right]$-tren, crystals were immersed in aqueous solutions of potassium and lithium chloride $(0.1 \mathrm{M}, 2 \mathrm{M}$ and $3 \mathrm{M})$ with $p \mathrm{H} \approx 6$. After heating the solutions at $343 \mathrm{~K}$, over periods ranging from $3 \mathrm{~h}$ to $5 \mathrm{~d}$. Crystals were also immersed in deionised water for $3 \mathrm{~h}$ at $343 \mathrm{~K}$ and room temperature for comparison. All crystal samples were then washed with ethanol, water and acetone. In each case, the soaking treatment resulted in a change in the colour of the crystals from yellow to orange. The TGA (Figure S4) and combustion analysis data for the solid products after immersion in water and alkali-metal chloride solutions (summarised in Table S3) are broadly similar.

On immersion in both water and the aqueous alkali-metal chloride solutions, there is a significant reduction in the organic content of the crystals (up to $50 \%$ ), suggesting the partial removal of tren molecules from the pore space. This loss of organic component is accompanied by an uptake of water into the crystals. Evidence for water incorporation is provided both by the weight losses observed in the TGA curves at low 
temperature $\left(\sim 100{ }^{\circ} \mathrm{C}\right)$ (Figure S4) and by the infrared data (Figure S5), where, in each case, there is an increase in the intensities of the $v(\mathrm{O}-\mathrm{H})$ and $\delta(\mathrm{H}-\mathrm{O}-\mathrm{H})$ bands at 3400 and $1640 \mathrm{~cm}^{-1}$, respectively. The uptake of alkali-metal ions on soaking in salt solutions, determined from atomic absorption spectroscopy (Table S6), is extremely low (<2.4 wt. $\%$ for $\mathrm{K}^{+}$, for example). This is much lower than would be expected on charge-balancing grounds were the alkali-metal ions to replace protonated amine. This suggests that the alkali-metal ions are merely absorbed on the crystal surface and that immersion of the title compound in alkali-metal solutions does not result in ionexchange. We suggest therefore that immersion in both water and alkali-metal chloride solutions leads to the removal of only the non-protonated amine from the pores and the product can be formulated as $\left(\mathrm{H}_{1.33} \operatorname{tren}\right)\left[\operatorname{In}_{2.67} \mathrm{Sb}_{1.33} \mathrm{~S}_{8}\right] \cdot(\operatorname{tren})_{1-y}\left(\mathrm{H}_{2} \mathrm{O}\right)_{x}$. There is some variation in the $x$ and $y$ values for samples produced on stirring in alkali-metal chloride solutions (Table S3), with $x$ in the range $2.5-4.7$ and $y$ in the range 0.7 to 1.0 , with the general trend that removal of neutral tren increases with increase in concentration of the alkali-metal salt solution. On stirring in $2 \mathrm{M} \mathrm{KCl}$ for $3 \mathrm{~h}$, the limiting value of $50 \%$ reduction in organic component is achieved, and the product has the composition $\left(\mathrm{H}_{1.33}\right.$ tren $)\left[\mathrm{In}_{2.67} \mathrm{Sb}_{1.33} \mathrm{~S}_{8}\right] \cdot\left(\mathrm{H}_{2} \mathrm{O}\right)_{4}$. For the samples immersed in water for $3 \mathrm{~h}$ at $343 \mathrm{~K}$ and room temperature, the TGA results show that in both cases, removal of all the neutral tren is not achieved. Tren removal is however greater at $343 \mathrm{~K}$ than at room temperature ( $y=0.67$ and $x=3.96$ and $y=0.22$ and $x=2.34$, respectively).

The soaked samples exhibit a decrease in crystallinity compared to the pristine samples as the concentration of alkali-metal chloride solution and soaking time increases, as evidenced by peak broadening in the powder X-ray diffraction patterns (Figure S6). However, unit-cell parameters could be measured for crystals soaked for $3 \mathrm{~h}$ in water, $0.1 \mathrm{M} \mathrm{KCl}, \mathrm{NaCl}$ and $\mathrm{LiCl}$ and $2 \mathrm{M} \mathrm{KCl}$ (Tables 4 and S4). Single-crystal 
X-ray data were indexed using the same tetragonal unit cell and space group as for the pristine material, and a maximum reduction of $\sim 9 \%$ in the unit-cell volume was observed in the case of $\left(\mathrm{H}_{1.33}\right.$ tren $)\left[\operatorname{In}_{2.67} \mathrm{Sb}_{1.33} \mathrm{~S}_{8}\right] \cdot\left(\mathrm{H}_{2} \mathrm{O}\right)_{4}$, obtained after immersion of the title compound in $2 \mathrm{M} \mathrm{KCl}$. A medium-resolution structure solution for a crystal soaked in $0.1 \mathrm{M} \mathrm{KCl}$ solution (Table S5) confirmed that the In-Sb-S framework structure has been retained.

Table 4: Lattice parameters determined at $150 \mathrm{~K}$ for single crystals produced following immersion for 3 hours in water ${ }^{\S}$ and $2 \mathrm{M} \mathrm{KCl}$ solution.

\begin{tabular}{lccc}
\hline & $a / \AA$ & $c / \AA$ & Cell Volume $/ \AA^{3}$ \\
$\left(\mathrm{H}_{1.33} \operatorname{tren}\right)\left[\operatorname{In}_{2.67} \mathrm{Sb}_{1.33} \mathrm{~S}_{8}\right] \cdot \operatorname{tren}$ & $12.6248(5)$ & $19.4387(18)$ & $3098.2(3)$ \\
$\left(\mathrm{H}_{1.33} \operatorname{tren}\right)\left[\operatorname{In}_{2.67} \mathrm{Sb}_{1.33} \mathrm{~S}_{8}\right] \cdot(\operatorname{tren})_{0.33} \cdot\left(\mathrm{H}_{2} \mathrm{O}\right)_{4}^{\S}$ & $12.4275(13)$ & $18.572(3)$ & $2868.3(8)$ \\
$\left(\mathrm{H}_{1.33} \operatorname{tren}\right)\left[\operatorname{In}_{2.67} \mathrm{Sb}_{1.33} \mathrm{~S}_{8}\right] \cdot\left(\mathrm{H}_{2} \mathrm{O}\right)_{4}^{\ddagger}$ & $12.348(3)$ & $18.574(8)$ & $2832.2(15)$
\end{tabular}

Diffuse reflectance data for products obtained after soaking in $0.1 \mathrm{M}$ solutions for 3 $\mathrm{h}$, show that the band gap is unaffected on replacing neutral tren molecules by water within the structure (Figure S7).

\section{Conclusions}

A novel indium-antimony sulfide, ( $\left.\mathrm{H}_{1.33} \operatorname{tren}\right)\left[\mathrm{In}_{2.67} \mathrm{Sb}_{1.33} \mathrm{~S}_{8}\right] \cdot \operatorname{tren}$, has been synthesised and structurally characterised. It contains adamantane-like $\left[\operatorname{In}_{2.67} \mathrm{Sb}_{1.33} \mathrm{~S}_{8}\right]^{1.33-} \mathrm{T} 2$ supertetrahedral clusters, constructed from $\mathrm{Sb}(\mathrm{V}) \mathrm{S}_{4}$ and $\mathrm{In}(\mathrm{III}) \mathrm{S}_{4}$ tetrahedra, which are linked through their terminal sulfur atoms into a threedimensional open-framework structure. Although it was not possible to locate the 
organic component, tren, directly using single-crystal X-ray diffraction data, its presence has been confirmed through ${ }^{13} \mathrm{C}$ solid-state NMR, infrared spectroscopy, combustion analysis and thermogravimetry. These data, together with the two-step weight loss observed in TGA, suggest that only one of the tren molecules is protonated in order to provide the required charge balancing for the anionic inorganic framework. Immersion of the material in either water or alkali-metal halide solutions leads, at the limit, to removal of approximately half of the organic component, consistent with removal of the non-protonated tren and inclusion of water to form $\left(\mathrm{H}_{1.33}\right.$ tren $)\left[\operatorname{In}_{2.67} \mathrm{Sb}_{1.33} \mathrm{~S}_{8}\right] \cdot\left(\mathrm{H}_{2} \mathrm{O}\right)_{4}$. This exchange reaction is accompanied by a reduction of $c a .9 \%$ in unit-cell volume.

\section{Acknowledgements}

The authors acknowledge the financial support for this work from the UK EPSRC and the University of Reading. We also thank the University of Reading for access to the Chemical Analysis Facility (CAF lab) and Mr Nick Spencer (X-ray lab technician) and Dr Radoslaw Kowalczyk (NMR technician) for assistance with data collections.

\section{References}

[1] F. Schüth and A. Taguchi, Microporous Mesoporous Mater., 2005, 77, 1-45.

[2] B. J. Riley, J. D. Vienna, D. M. Strachen, J. S. McCloy and J. L. Jerden, J. Nucl Mater., 2016, 470, 307-326.

[3] N. F. Zheng, X. H. Bu, B.Wang and P. Y. Feng, Science, 2002, 298, 2366-2369.

[4] K. -Y. Wang, M. -L. Feng, J. -R. Li and X. -Y. Huang, J. Mater. Chem., 2013, A1, 1709-1715.

[5] H. Ahari, C. L. Bowes, T. Jiang, A. Lough, G. A. Ozin, R. L. Bedard, S. Petrov and D. Young, Adv. Mater. 1995, 7 (4), 375-378.

[6] N. Zheng, X. Bu, H. Vu and P. Feng, Angew. Chem. Int. Ed., 2005, 44, 5299 -5303. 
[7] H. A. Graf and H. Schafer, Z. Naturforsch., 1972, 27b, 735-739.

[8] R. L. Bedard, S. T. Wilson, L. D. Vail, J. M. Bennett, E.M. Flanigen, P.A. Jacobs and R. A. van Santen (Eds.), Zeolites: Facts, Figures, Future, Proceedings of the $8^{\text {th }}$ International Zeolite Conference, Elsevier, Amsterdam, 1989, p. 375.

[9] X. J. Meng and F. S. Xiao, Chem. Rev., 2014, 114, 1522-1544.

[10] Y. Shen, C. Liu, P. Hou, M. Zhi, C. Zhou, W. Chai, J.-W. Cheng, Y. Liu and Q. Zhang, Chem . Asian J., 2015, 10(12), 2603-2607.

[11] W. T. Chen, Z. G. Luo, Y. F. Wang, X. Zhang and H.-H. Fu, Inorg. Chim. Acta, 2014, 414, 1-7.

[12] G. Cordier, H. Schafer and C. Schwidetzky, Z. Naturforsch. 1984, 39b, 131-134.

[13] W. S. Sheldrick and H. J. Z. Hausler, Anorg. Allg. Chem., 1988, 557, 105-111.

[14] J. Zhou, L. An, X. Liu, L. Huang and X. Huang, Dalton Trans., 2011, 40, 11419-11424.

[15] D. -X. Jia, J. Dai, Q. -Y. Zhu, L. -H. Cao and H. -H. Lin, J. Solid State Chem., 2005, 178, 874-881.

[16] H. O. Stephan and M. G. Kanatzidis, Inorg. Chem., 1997, 36, 6050-6057.

[17] A. V. Powell, Int. J. Nanotechnol., 2011, 8, 783-794.

[18] R. Kiebach, C. Nather and W. Bensch, Z. Naturforsch., 2004, 56b, 1314-1319.

[19] R. Stähler and W. Bensch, Eur. J. Inorg. Chem., 2001, 12, 3073-3078.

[20] C. -C. Ou and C. -S. Yang, in Metal Chalcogenides Tetrahedral Molecular Clusters:

Crystal Engineering and Properties,: S. O. Ferreira (Ed), Advanced Topics on Crystal

Growth, Intech., 2013, Chapter 13 pp 403-423. Available from:

http://www.intechopen.com/books/advanced-topics-on-crystal-growth.

[21] X. Zhang, W. Luo, Y. -P Zhang, J. -B Jiang, Q. -Y Zhu and J. Dai, Inorg. Chem., 2011, 50, 6972-6978.

[22] R. J. E. Lees, A. V. Powell and A. M. Chippindale, J. Phys. Chem. Solids., 2007, 68, 1215-1219.

[23] Q. -G. Enrique, C. Nather and W. Bensch, Z. Naturforsch., 2009, 64b, 1312-1318.

[24] J. Zhou, X. Liu, L. T. An, F. L. Hu, Y. H. Kan, R. Li and Z. M. Shen, DaltonTrans., 2013, 42, 1735-1742.

[25] C. Anderer, C. Nather and W. Bensch. Inorg. Chem. Commun., 2014, 46, 335-339.

[26] X. Wang, T. -L. Sheng, S.-M. Hu, R.-B. Fu and X.-T. Wu. Inorg. Chem. Commun., 2009, 12, 399-401. 
[27] K.-Y. Wang, M. L. Feng, L.-J. Zhou, J.R. Li, X.-H. Qi and X. -Y. Huang, Chem. Commun., 2014, 50, 14960-14963

[28] J. Zhou, G. -Q. Bian, J. Dai, Y. Zhang, A. -B. Tang and Q. -Y. Zhu, Inorg Chem., 2007, 46, 1541-1543.

[29] Q. Zhang, X. Bu, Z. Lin, M. Biasini, W. P. Beyermann, and P. Feng., Inorg Chem., 2007, 46, 7262-7264.

[30] C. L. Cahill and J. B. Parise, J. Chem. Soc. Dalton Trans., 2000, 1475-1482.

[31] Z. X. Lei, Q. -Y. Zhu, X. Zhang, W. Luo, W. Q. Mu and J. Dai, Inorg Chem. 2010, 49, 4385-4387.

[32] T. Wu, X. Bu, P. Liao, L. Wang, S. -T. Zheng, R. Ma and P. Feng, J. Am. Chem. Soc., 2012, 134 (8), 3619-3622.

[33] B. Eisenmann and A. Hofmann, Z. für Kristallogr., 1991, 195, 318-319.

[34] Z. Su, X. Li, Y. Lan, G. Jin, J. Xie, C. Zheng, J. Jin and S. Li, Mater Lett., 2008, 62, 2802-2805.

[35] C. Wang, Y. Li, X. Bu, N. Zheng, P. Zivkovic, C. -S. Yang and P. Feng, J. Am. Chem. Soc., 2001, 123, 11506-11507.

[36] D. Pitzschke, C. Nather and W. Bensch, Solid State Sci., 2002, 4, 1167-1171.

[37] K. Y. Wang, M. -L. Feng, X.-Y. Huang and J. Li, Coord. Chem. Rev. 2016, 322, 41-68.

[38] X. Liu. Inorg. Chem. Commun., 2011, 14, 437-439.

[39] N. Ding and M. G. Kanatzidis, Chem. Mater., 2007, 19, 3867-3869.

[40] J. Zhou, L. An and F. Zhang, Inorg. Chem., 2011, 50, 415-417.

[41] P. Vaqueiro, D. P. Darlow, A.V. Powell and A. M. Chippindale, Solid State Ionics, 2004, 172, 601-604.

[42] B. Karvaly and I. Hevesi, Z. Naturforsch., 1971, 26a, 245-249.

[43] A. Altomare, G. Cascarano, C. Giacovazzo, and J. Guagliardi., J. Appl. Crystallogr., 1993, 26, 343-350.

[44] P. W. Betteridge, J. R. Carruthers, R. I. Cooper, K. Prout and D. J. Watkin, J. Appl. Crystallogr., 2003, 36, 1487.

[45] P. V. D. Sluis, and A. L. Spek,. Acta Cryst., 1990, A46, 194-201.

[46] B. D. A. Levin, M. J. Zachman, J. G. Werner, U. Wiesner, L. F. Kourkoutis and D.

A. Muller, Microsc. Microanal., 2014, 20, 446-447.

[47] M. Schur, H. Rijnberk, C. Nather and W. Bensch, Polyhedron, 1998, 18, 101-107. 
[48] W. M. Hutchinson, A. R. Collett, and C. L. Lazzell, J. Am. Chem. Soc., 1945, 67, 1966-1968.

[49] S. Satapathi, Inorg. Chem. Commun., 2015, 56, 89-101.

[50] A. V. Powell, R. J. E. Lees and A. M. Chippindale, J. Phys. Chem. Solids., 2008, 69, 1000-1006.

[51] A.V. Powell and R. Mackay, J. Solid State Chem., 2011, 184, 3144-3149. 